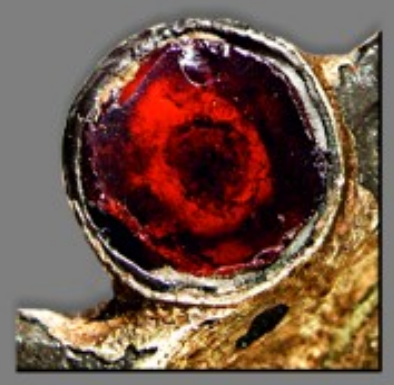

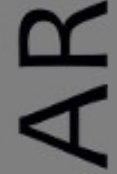

$\sim$

ш
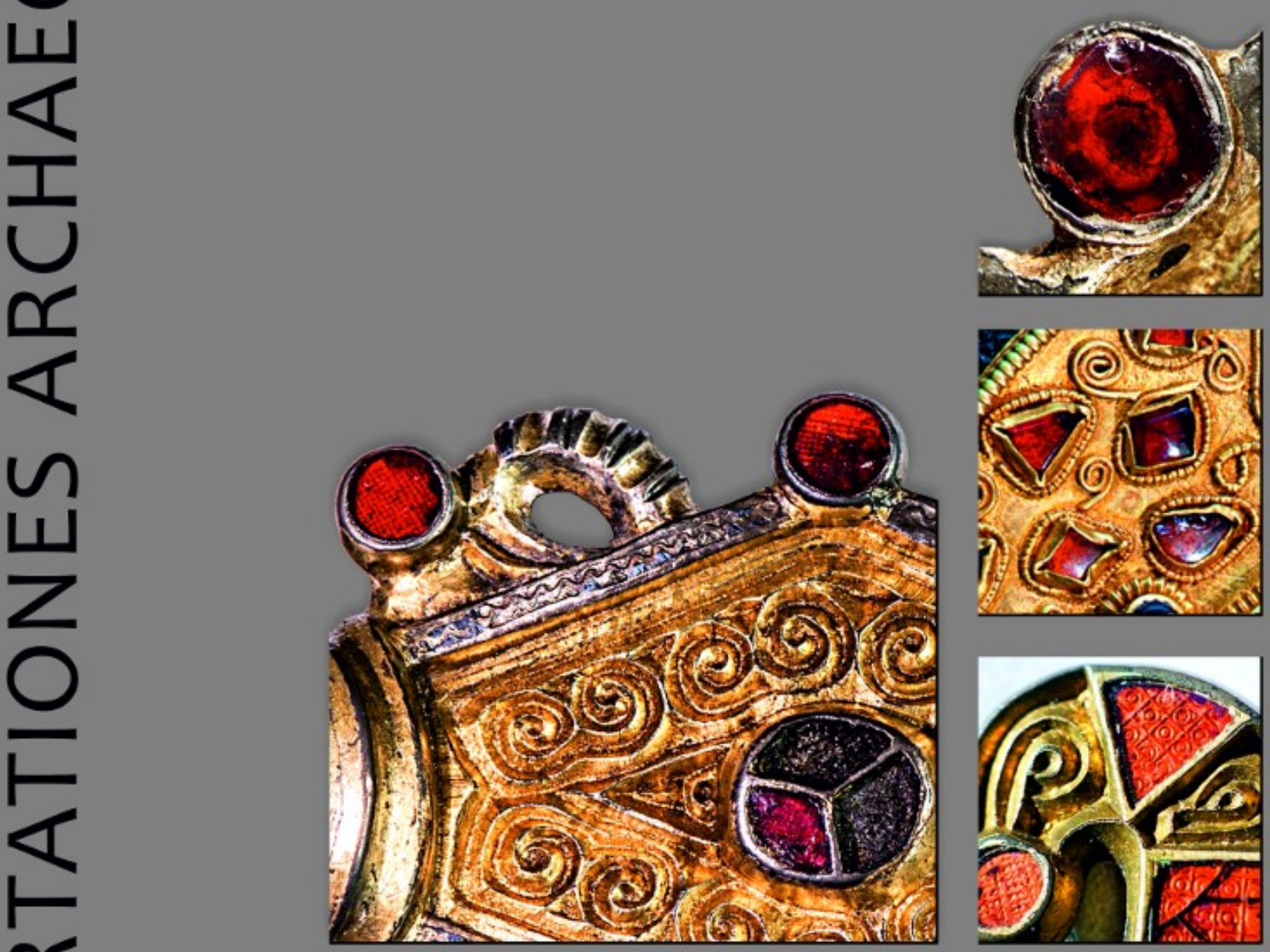

E

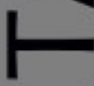

œ

山

n

ก

$\overline{0}$
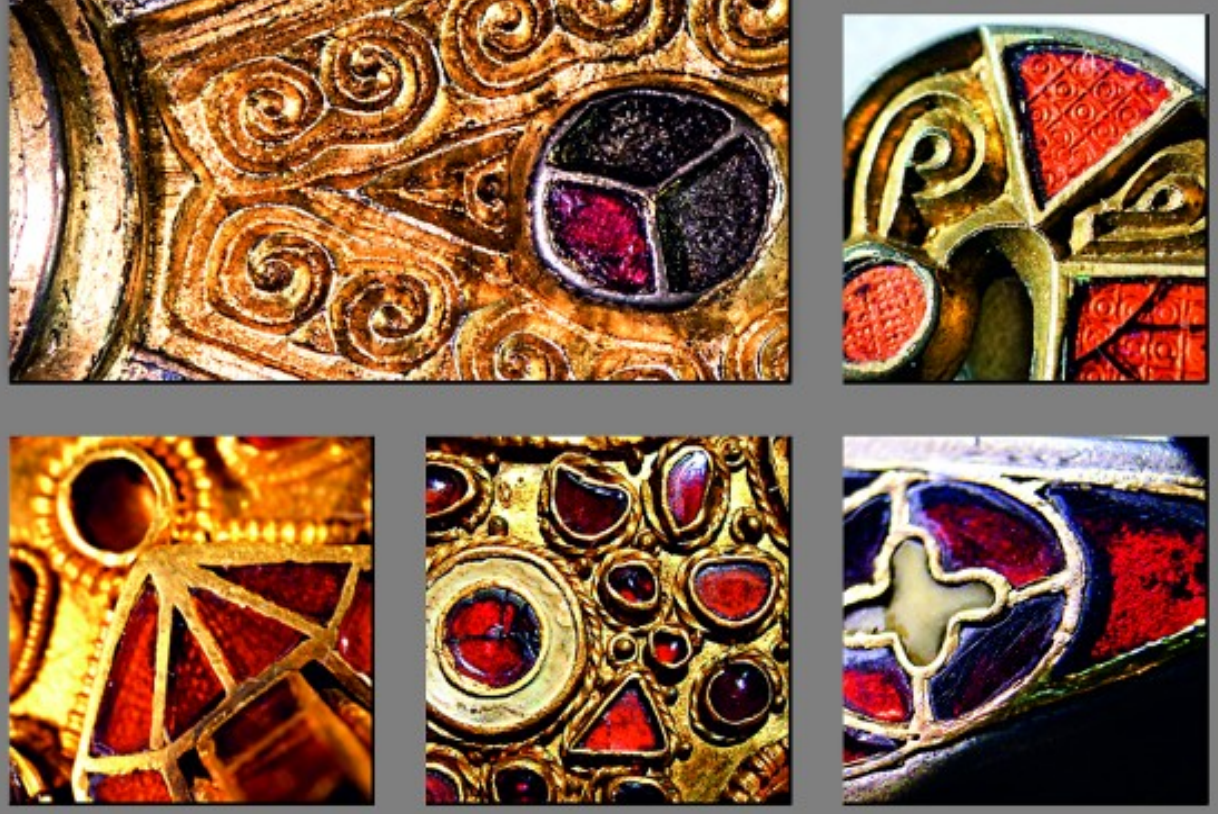

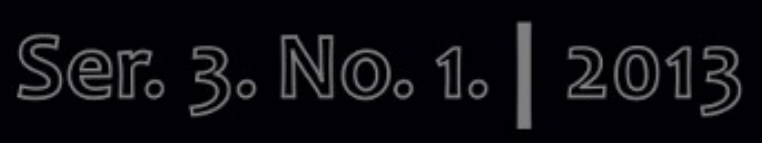




\section{Dissertationes Archaeologicae ex Instituto Archaeologico}

Universitatis de Rolando Eötvös nominatae Ser. 3. No. 1.

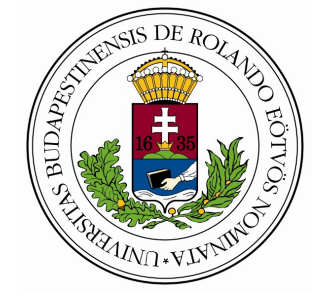

Budapest 2013 
Dissertationes Archaeologicae ex Instituto Archaeologico

Universitatis de Rolando Eötvös nominatae

Ser. 3. No. 1.

Editor-in-chief:

DÁvid BARTUS

Editorial board:

LÁSZLÓ BARTOSIEWICZ

LÁSZLÓ BORHY

ISTVÁN FELD

GÁBOR KALLA

PÁL RACZKY

Miklós SzABÓ

TIVADAR VIDA

Technical editors:

DÁvid BARTuS

GÁBOR VÁCZI

ANDRÁs BöDŐcs

Proofreading:

Zsófia KondÉ

SzILvia SzÖLlősI

Available online at http://dissarch.elte.hu

Contact: dissarch@btk.elte.hu

\section{$\underline{\text { PKP }}$ \\ PUBLIC \\ KNOWLEDGE \\ PROJECT}

(C) Eötvös Loránd University, Institute of Archaeological Sciences

Budapest 2013 


\section{Contents}

\section{Articles}

Melinda TORBÁGYI - István VIDA

The coin hoard of Abasár

Anikó BózsA

21

Roman mirrors from a private collection in the Hungarian National Museum

Lajos JuHÁsz

45

The Biesheim cameo - a reinterpretation

\section{Methods}

Péter CsIPpÁN

$A z$ állatcsont, mint információhordozó leletanyag

Kata DÉvAI

Terminológiai alapfogalmak régészeti korú üvegtárgyak elemzéséhez

Lőrinc TimáR - Zoltán Czajlik - Sándor Puszta - Balázs Holl

$3 D$ reconstructions using GPR data at the Mont Beuvray

\section{FIELD REPORTS}

Zsolt MESTER

Excavation at a new Upper Palaeolithic site of the Eger region (Northern Hungary)

László BORHY - Dávid BARTus - Emese SzÁmadó

Short report on the excavations at Brigetio (Szőny-Vásártér) in 2013

Dénes HulLÁm - Zsófia RÁcz

Report on the participation of the Eötvös Loránd University at the Wielbark Archaeological Field School in Malbork-Wielbark, Poland

Gábor VÁczi - Dávid BARTus

Short report on the excavations at the site Makó - Igási Ugar

Maxim MoRdovin

Short report on the excavations in 2013 of the Department of Hungarian Medieval and Early Modern Archaeology (Eötvös Loránd University, Budapest)

\section{THESIS ABSTRACTS}

Kitti KÖHLER

Biological reconstruction of the Late Neolithic Lengyel Culture 
Cultural connections and interactions of Eastern Transdanubia during the Urnfield period

Orsolya LÁNG

Urban problems in the civil town of Aquincum: the so-called „northern band”

Nikoletta SEY

Questions of bronze workshops in Roman Pannonia

Kata DÉvaI

Glass vessels from Late Roman times found in graves in the Hungarian part of Pannonia

Eszter HORvÁTH

Gemstone and glass inlaid fine metalwork from the Carpathian Basin:

the Hunnic and Early Merovingian Periods

Gergely SzEnTHE

Vegetal ornaments in the Late Avar decorative art

Péter LANGó

Relations between the Carpathian Basin and South East Europe during the 10th century.

The evidence of the minor objects

Ciprián HoRvÁTH

The Cemeteries and Grave Finds of Györ and Moson Counties from the Time

of the Hungarian Conquest and the Early Árpádian Age

András Sófalvi

The border- and self-defence of Szeklers from the Medieval Age till the Age of Principality.

Castles and other defence objects in the settlement history of Udvarhelyszék 


\title{
The coin hoard of Abasár
}

MELINDA TORBÁgyi

Hungarian National Museum

torbagyi.melinda@hnm.hu
ISTVÁN VIDA

Hungarian National Museum

vida.istvan@hnm.hu

\begin{abstract}
The composition of the small hoard found on the northern edge of the Great Plain is very interesting and unique in Hungary, as Celtic tetradrachms and small change were hidden along with Roman Republican and Imperial denarii. The peculiar composition of the hoard suggests the treasure was aggregated by several generations of the owner's family. The silver ingot indicates that the hoard was treated as bullion rather than money, which attests the lack of regular coin circulation in the Celtic Carpathian basin. The Lapujto type coins of the hoard denote eastern connections, they probably mark the arrival of Celts fled before the Dacians. The Roman coins might indicate the establishment of an ally system as a part of the Augustean foreign politics, and based on the coins it existed even during the reign of Tiberius.
\end{abstract}

The date and the exact location of the find are unknown. The coins were scattered on a small area, vessel or its fragments were not found. The hoard contained 9 Celtic silver coins, 39 Roman Republican denarii, 4 Roman imperial denarii and a silver ingot (Fig. 4-6):

\begin{tabular}{|c|c|c|c|c|c|c|c|c|}
\hline 1 & Later derivation of Audoleon type & & $\operatorname{tdr}^{1}$ & & Pink & $406^{2}$ & $11.24 \mathrm{~g}$ & $3 \mathrm{~h}$ \\
\hline 2 & Later Lapujtő type & & $\operatorname{tdr}$ & & Pink & $369^{3}$ & $11.38 \mathrm{~g}$ & \\
\hline 3 & Later Lapujtő type & & $\operatorname{tdr}$ & & Pink & 369 & $10.91 \mathrm{~g}$ & \\
\hline 4 & Later Lapujtő type & & $\operatorname{tdr}$ & & Pink & 369 & $10.68 \mathrm{~g}$ & \\
\hline 5 & Later Lapujtő type & & $\operatorname{tdr}$ & & Pink & 369 & $10.28 \mathrm{~g}$ & \\
\hline 6 & Lapujtő type & & $\mathrm{dr}$ & & Pink & 370 & $2.66 \mathrm{~g}$ & $12 \mathrm{~h}$ \\
\hline 7 & Imitation of Philip II of Macedon & & $\operatorname{tdr}$ & & & & $4.07 \mathrm{~g}$ & \\
\hline 8 & uncertain type $^{4}$ & & obol & & & & $0.79 \mathrm{~g}$ & $6 \mathrm{~h}$ \\
\hline 9 & "Hippo-bird" ${ }^{5}$ type & & obol & & & & $0.42 \mathrm{~g}$ & $12 \mathrm{~h}$ \\
\hline 10 & ingot & & & & & & $6.10 \mathrm{~g}$ & \\
\hline 11 & uncertain moneyer & Rome? & $\mathrm{d}$ & $2^{\text {nd }}$ century BC & $\mathrm{RRC}$ & $?$ & $3.64 \mathrm{~g}$ & $6 \mathrm{~h}$ \\
\hline 12 & uncertain moneyer & Rome? & $\mathrm{d}$ & $2^{\text {nd }}$ century BC & $\mathrm{RRC}$ & $?$ & $3.47 \mathrm{~g}$ & $1 \mathrm{~h}$ \\
\hline 13 & anonymous & Rome & $\mathrm{d}$ & $157-156 \mathrm{BC}$ & $\mathrm{RRC}$ & $197 / 1 \mathrm{a}$ & $3.03 \mathrm{~g}$ & $1 \mathrm{~h}$ \\
\hline 14 & anonymous & Rome & $\mathrm{d}$ & $157-156 \mathrm{BC}$ & $\mathrm{RRC}$ & $197 / 1 \mathrm{a}$ & $3.67 \mathrm{~g}$ & $12 \mathrm{~h}$ \\
\hline 15 & P. Aelius Paetus & Rome & d & $138 \mathrm{BC}$ & $\mathrm{RRC}$ & $233 / 1$ & $3.37 \mathrm{~g}$ & $12 \mathrm{~h}$ \\
\hline 16 & T. Quinctius Flaminius & Rome & $d$ & $126 \mathrm{BC}$ & $\mathrm{RRC}$ & $267 / 1$ & $3.45 \mathrm{~g}$ & $12 \mathrm{~h}$ \\
\hline 17 & M. Papirius Carbo & Rome & $\mathrm{d}$ & $122 \mathrm{BC}$ & $\mathrm{RRC}$ & $276 / 1$ & $3.36 \mathrm{~g}$ & $6 \mathrm{~h}$ \\
\hline
\end{tabular}

1 The original names of the Celtic coins are unknown; we use the current terminology to refer to the size of the coins.

2 LANZ 709; KHM 1326-1327.

3 LANZ 685-686; TORBÁGYI 2000, 57; DESS 280; FORRER 283.

4 The photo of the reverse is lost.

5 The name of this previously unknown type was given by us. 
Melinda ToRBÁgyi - István VIDA

\begin{tabular}{|c|c|c|c|c|c|c|c|c|}
\hline 18 & $\begin{array}{l}\text { Q. Curtius } \\
\text { \& M. Silanus }\end{array}$ & Rome & $\mathrm{d}$ & 116 or $115 \mathrm{BC}$ & $\mathrm{RRC}$ & $285 / 2$ & $3.49 \mathrm{~g}$ & $9 \mathrm{~h}$ \\
\hline 19 & L. Flaminius Chilo & Rome & $d$ & 109 or $108 \mathrm{BC}$ & $\mathrm{RRC}$ & $302 / 1$ & $3.51 \mathrm{~g}$ & $3 \mathrm{~h}$ \\
\hline 20 & L. Flaminius Chilo & Rome & d & 109 or $108 \mathrm{BC}$ & $\mathrm{RRC}$ & $302 / 1$ & $3.48 \mathrm{~g}$ & $9 \mathrm{~h}$ \\
\hline 21 & Q. Titius & Rome & $\mathrm{d}$ & $90 \mathrm{BC}$ & $\mathrm{RRC}$ & $341 / 2$ & $3.55 \mathrm{~g}$ & $12 \mathrm{~h}$ \\
\hline 22 & $\begin{array}{l}\text { C. Gargonius } \\
\text { \& Ogulnius } \\
\text { \& Vergilius }\end{array}$ & Rome & $\mathrm{d}$ & $86 \mathrm{BC}$ & $\mathrm{RRC}$ & $350 \mathrm{~A} / 1 \mathrm{~b}$ & $3.34 \mathrm{~g}$ & $12 \mathrm{~h}$ \\
\hline 23 & C. Licinius Macer & Rome & $\mathrm{d}$ & $84 \mathrm{BC}$ & $\mathrm{RRC}$ & $354 / 1$ & $3.69 \mathrm{~g}$ & $6 \mathrm{~h}$ \\
\hline 24 & Q. Caecilius Metellus Pius & North Italy & d & $81 \mathrm{BC}$ & $\mathrm{RRC}$ & $374 / 1$ & $3.54 \mathrm{~g}$ & $6 \mathrm{~h}$ \\
\hline 25 & Ti. Claudius Nero & Rome & d & $79 \mathrm{BC}$ & $\mathrm{RRC}$ & $383 / 1$ & $3.34 \mathrm{~g}$ & $6 \mathrm{~h}$ \\
\hline 26 & P. Cornelius Lentulus Spinther & Rome & d & $74 \mathrm{BC}$ & $\mathrm{RRC}$ & $397 / 1$ & $3.41 \mathrm{~g}$ & $5 \mathrm{~h}$ \\
\hline 27 & C. Hosidius Geta & Rome & d & $68 \mathrm{BC}$ & $\mathrm{RRC}$ & $407 / 2$ & $3.61 \mathrm{~g}$ & $6 \mathrm{~h}$ \\
\hline 28 & C. Piso Frugi & Rome & $\mathrm{d}$ & $67 \mathrm{BC}$ & $\mathrm{RRC}$ & $408 / 1 b$ & $2.98 \mathrm{~g}$ & $6 \mathrm{~h}$ \\
\hline 29 & C. Julius Caesar & moving mint & $d$ & $49-48 \mathrm{BC}$ & $\mathrm{RRC}$ & $443 / 1$ & $3.42 \mathrm{~g}$ & $12 \mathrm{~h}$ \\
\hline 30 & D. Junius Brutus Albinus & Rome & d & $48 \mathrm{BC}$ & $\mathrm{RRC}$ & $450 / 2$ & $3.63 \mathrm{~g}$ & $11 \mathrm{~h}$ \\
\hline 31 & L. Plautius Plancus & Rome & $d$ & $47 \mathrm{BC}$ & $\mathrm{RRC}$ & $453 / 1 \mathrm{a}$ or $1 \mathrm{~b}$ & $3.57 \mathrm{~g}$ & $12 \mathrm{~h}$ \\
\hline 32 & T. Carisius & Rome & $\mathrm{d}$ & $46 \mathrm{BC}$ & $\mathrm{RRC}$ & $464 / 1$ & $3.46 \mathrm{~g}$ & $2 \mathrm{~h}$ \\
\hline 33 & T. Carisius & Rome & d & $46 \mathrm{BC}$ & $\mathrm{RRC}$ & $464 / 3 a$ & $3.67 \mathrm{~g}$ & $3 \mathrm{~h}$ \\
\hline 34 & L. Aemilius Buca & Rome & $d$ & $44 \mathrm{BC}$ & $\mathrm{RRC}$ & $480 / 6$ & $3.35 \mathrm{~g}$ & $3 \mathrm{~h}$ \\
\hline 35 & P. Clodius & Rome & d & $42 \mathrm{BC}$ & RRC & $494 / 23$ & $3.61 \mathrm{~g}$ & $2 \mathrm{~h}$ \\
\hline 36 & P. Clodius & Rome & d & $42 \mathrm{BC}$ & $\mathrm{RRC}$ & $494 / 23$ & $2.87 \mathrm{~g}$ & $2 \mathrm{~h}$ \\
\hline 37 & L. Mussidius Longus & Rome & $\mathrm{d}$ & $42 \mathrm{BC}$ & $\mathrm{RRC}$ & $494 / 39 a$ & $3.58 \mathrm{~g}$ & $10 \mathrm{~h}$ \\
\hline 38 & $\begin{array}{l}\text { M. Junius Brutus } \\
\text { \& Pedanius Costa }\end{array}$ & moving mint & $\mathrm{d}$ & $43-42 \mathrm{BC}$ & $\mathrm{RRC}$ & $506 / 2$ & $3.58 \mathrm{~g}$ & $12 \mathrm{~h}$ \\
\hline 39 & Cn. Domitius Ahenobarbus & moving mint & $d$ & $41 \mathrm{BC}$ & $\mathrm{RRC}$ & $519 / 2$ & $3.35 \mathrm{~g}$ & $7 \mathrm{~h}$ \\
\hline 40 & M. Antonius & moving mint & $d$ & $38 \mathrm{BC}$ & $\mathrm{RRC}$ & $533 / 2$ & $3.72 \mathrm{~g}$ & $6 \mathrm{~h}$ \\
\hline 41 & $\begin{array}{l}\text { C. Julius Caesar Octavianus } \\
\text { \& M. Vipsanius Agrippa }\end{array}$ & moving mint & $\mathrm{d}$ & $38 \mathrm{BC}$ & $\mathrm{RRC}$ & $534 / 3$ & $3.72 \mathrm{~g}$ & $12 \mathrm{~h}$ \\
\hline 42 & M. Antonius & moving mint & d & $33 \mathrm{BC}$ & RRC & $542 / 2$ & $3.60 \mathrm{~g}$ & $9 \mathrm{~h}$ \\
\hline 43 & M. Antonius & moving mint & d & $32-31 \mathrm{BC}$ & RRC & $544 / 16$ & $3.17 \mathrm{~g}$ & $6 \mathrm{~h}$ \\
\hline 44 & M. Antonius & moving mint & d & $32-31 \mathrm{BC}$ & $\mathrm{RRC}$ & $544 / 19$ & $3.43 \mathrm{~g}$ & $6 \mathrm{~h}$ \\
\hline 45 & M. Antonius & moving mint & d & $32-31 \mathrm{BC}$ & $\mathrm{RRC}$ & $544 / 26$ & $3.44 \mathrm{~g}$ & $3 \mathrm{~h}$ \\
\hline 46 & M. Antonius & moving mint & d & $32-31 \mathrm{BC}$ & $\mathrm{RRC}$ & $544 / 27$ & $3.29 \mathrm{~g}$ & $6 \mathrm{~h}$ \\
\hline 47 & M. Antonius & moving mint & d & $32-31 \mathrm{BC}$ & $\mathrm{RRC}$ & $544 / 30$ & $2.68 \mathrm{~g}$ & $1 \mathrm{~h}$ \\
\hline 48 & M. Antonius & moving mint & $\mathrm{d}$ & $32-31 \mathrm{BC}$ & $\mathrm{RRC}$ & $544 / 31$ & $3.58 \mathrm{~g}$ & $2 \mathrm{~h}$ \\
\hline 49 & C. Julius Caesar Octavianus & Brundisium? & d & c. $32-29 \mathrm{BC}$ & RIC & $250 \mathrm{~b}$ & $3.53 \mathrm{~g}$ & $3 \mathrm{~h}$ \\
\hline 50 & Augustus & Colonia Patricia? & d & c. $18 \mathrm{BC}$ & RIC & 100 & $3.42 \mathrm{~g}$ & $4 \mathrm{~h}$ \\
\hline 51 & Augustus & Rome & d & $13 \mathrm{BC}$ & RIC & 410 & $3.66 \mathrm{~g}$ & $11 \mathrm{~h}$ \\
\hline 52 & Tiberius & Rome & $\mathrm{d}$ & $14-37$ & RIC & 26 & $3.66 \mathrm{~g}$ & $7 \mathrm{~h}$ \\
\hline 53 & Trajan & Rome & d & $103-111$ & RIC & 118 & $2.80 \mathrm{~g}$ & $6 \mathrm{~h}$ \\
\hline
\end{tabular}


Hoards including Celtic coins together with Roman ones - except for the Eravisci - are atypical in the Carpathian basin. In a few cases Roman Republican coins were found together with contemporary barbarous imitations, but in Imperial times only counterfeits are found. The silver ingot in the hoard implies that the coins were primarily treated as silver and not as money. This corresponds with the monetary scarce finds of the Barbarian territories of the Carpathian basin suggesting no regular monetary circulation and coin use.

\section{Celtic coins}

There are two well-known Celtic coin types in the hoard, a later variation of the Audoleon imitations, and Lapujtő type coins, including a small denomination. The terminology of Celtic coins minted in the Carpathian basin is rather complicated. Karl Pink, who wrote the first monographic work on eastern Celtic coinage, classified the types in geographical groups, based on a line of degeneration; that is greater distance in time and space from the original means later mintage. ${ }^{6}$ In case he could not connect the coins to Celtic tribes Pink named the particular types after their characteristic depiction, such as Bartkranzavers, Zügelpferd, or Zopfreiter to mention only a few examples. Hungarian, Romanian, and Slovakian researchers primarily use geographical names, i.e. the type is named after its first great hoard. Thus Bartkranzavers is also called Crişeni Berchiş type, ${ }^{7}$ Zügelpferd is also called Velký Bysterec type, ${ }^{8}$ Zopfreiter is also called Mászlonypuszta type. ${ }^{9}$ Pink’s catalogue - although it is outdated in many aspects - is still a reference-catalogue regarding typology, its naming is also mentioned in modern, not German-language catalogues.

Several exemplars of the so-called Lapujtö-type are in the hoard. The obverse of the four larger ones - usually called tetradrachms - is a plain or shallowly indented bulge. This type of obverse is called Buckelavers by Pink, but this is only a technical feature caused by diewear. There was no demand and skill to make new dies, thus the old ones were used limitlessly. These Buckelaverses can be found at several locations of the Celtic world struck in both gold and silver (DLT 6920, 8592, 8704, 8744, 9368, 10059), and they also occur on the Balkans on Thracian-Getic territory (Lanz 922-932). Buckelaverses make up a specific group in the northern part of the Carpathian basin; particular types are typical for the Karancs ${ }^{10}$ (Nógrád megye) and Bükk ${ }^{11}$ (Borsod-Abaúj-Zemplén megye) mountains, other ones are typical for northern Slovakia. ${ }^{12}$

The Lapujto type coins are quite rare, only the Coin Cabinet of the Hungarian National Museum (MNM) has several pieces; almost all of them (even the coins with revisional inventory numbers) are from the hoard of Karancs-hegyalja found in 1868. The shepherd boy of the landowner Ferenc Szontagh found it amongst the mouldered remains of a pottery (unfortunately the pottery was lost). According to Szontagh ${ }^{13}$ the treasure consisted of "79 larger, 22 smaller and 7 smallest coins". Five of these coins - "three large ones, one smaller one, and one smallest one" were inventoried in the Coin Cabinet of the MNM (Inv. nr. 11.1870.1-4). In 1905 six other pieces

\footnotetext{
6 PINK 1974.

7 Preda 1973, 97-104.

8 EISNER 1927, 16-17; KolNíKOvA 1978, 59.

9 TORBÁgyi 2000, 33.

10 Gohl 1901, 406; Gohl 1904, 6.

11 GoHL 1904, 4; LeSzIH 1908, 98-99.

12 Kolníkova 2004.

13 Szontagh 1870, 292.
} 
were bought also from Szontagh (Inv. nr. 23.1905.1-6). It is not sure when and how other coins (Twelwe pieces: five tetradrachms, five drachms and two obols) with no inventory numbers were acquired; but they are likely to be from the same hoard, as their card was also written by Ödön Gohl, and they are inscribed "from the hoard of Lapujto". ${ }^{14}$

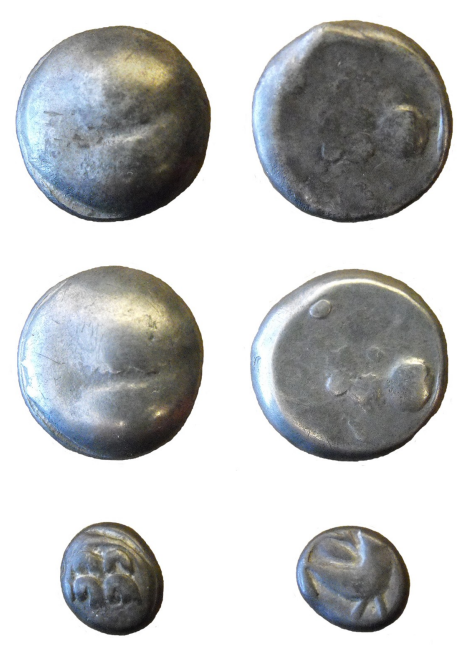

Fig. 1 .

In other collections there are only a few pieces of these rare coins: one was in the Dessewffy collection ${ }^{15}$ (MNM Dess. 280; $10.30 \mathrm{~g}$ ), one - reportedly from Hont vármegye - was in the Forrer collection (Forrer 283; $10.55 \mathrm{~g}$ ), and Pink mentioned a coin from Óhuta ${ }^{16}$ in the Windischgraetz collection (WG 2883; $11.00 \mathrm{~g}$ ). There is one coin in the Kunsthistorisches Museum (KHM 1286a; $11.00 \mathrm{~g}$ ), and there are two coins in the Lanz collection (Lanz 685-686; $10.81 \mathrm{~g}$; $10.02 \mathrm{~g})$. There were three coins in the Niklovits collection ${ }^{17}$ (MNM Ét N.I. 5330-32.; 10.91 g; 11.02 g; 11.35 g), while the Celtic catalogue of the British Museum ${ }^{18}$ mentions one coin from the Ashmolean Museum (S 90; $10.17 \mathrm{~g})$.

We also know three coins in a private collection (Fig. 1), which were found together near Karancslapujtő (two tetradrachms: $10.32 \mathrm{~g}$ and $10.29 \mathrm{~g}$, one obol: $2.02 \mathrm{~g}$ ). They might be the fragment of a larger hoard. In the recent years only two coins of this type were auctioned, both were tetradrachms $\left(11.06 \mathrm{~g}^{19} ; 10.65 \mathrm{~g}^{20}\right)$.

Ödön Gohl identified the Dess 802 / Pink 367 type, where the horseman on the reverse is clearly visible, as the prototype of the Lapujtö coins. ${ }^{21}$ Later this was affirmed by both Pink ${ }^{22}$ and Göbl, ${ }^{23}$ but the origin of the type can be traced even further, to earlier times. There are coins also from Karancslapujtő (early Lapujtő type) with discernible bearded head of Zeus on the obverse, and the horseman on the reverse is also well visible (Pink 353-355). These coins are significantly heavier; they weigh 13-14 g. This type can be derived from the Bough-rider type (Baumreiter mit Bartkranzavers; Pink 129-130), it is the latter's coarsened variation, it is likely that they were minted by the worn dies of the Bartkranzavers type. Though the design of the two types differs immensely, the coins of both types weigh more than $13 \mathrm{~g}$. Besides the Karancslapujtő coins we know the find spot of a single coin only; the Herman Ottó Múzeum at Miskolc has a coin (13.49 g) from Felsőkelecsény (Fig. 2). ${ }^{24}$

Unfortunately later Lapujtő type coins are not known from archaeological context, or from hoards well dated by other coins; thus their dating can be based only on typology and metrology. The weight of the four tetradrachms in the Abasár hoard is: $11.38 \mathrm{~g}, 10.91 \mathrm{~g}, 10.68 \mathrm{~g}$ and $10.28 \mathrm{~g}$. The weight of the same type coins in the MNM is: $11.67 \mathrm{~g}, 11.44 \mathrm{~g}, 11.38 \mathrm{~g}, 11.25 \mathrm{~g}$, $11.21 \mathrm{~g}, 11.06 \mathrm{~g}, 10.96 \mathrm{~g}, 10.95 \mathrm{~g}, 10.79 \mathrm{~g}, 10.62 \mathrm{~g}, 10.58 \mathrm{~g}, 10.58 \mathrm{~g}, 10.40 \mathrm{~g}$, and $10.23 \mathrm{~g}$.

14 The hoard is mentioned on different names. Karancs-hegyalja means 'at the bottom of Mount Karancs', Lapujtő is now Karancslapujtö, a village by the mountain.

15 Now it is in the collection of MNM.

16 Óhuta is now called Bükkszentlászló, and it is a part of Miskolc.

17 Now they are in the collection of MNM.

18 BMCC.

19 UBS Gold \& Numismatics, Auction 57 (15 September 2003), Lot 17.

20 Comptoir Général Financier, Mail Bid Sale 23 (27 November 2004), Lot 893.

21 GoHL 1911, 25.

22 Pink 1974.

23 GöBl 1973, Taf. 30.

24 Hellebrandt 1992, 60. 


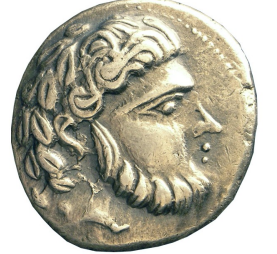

1
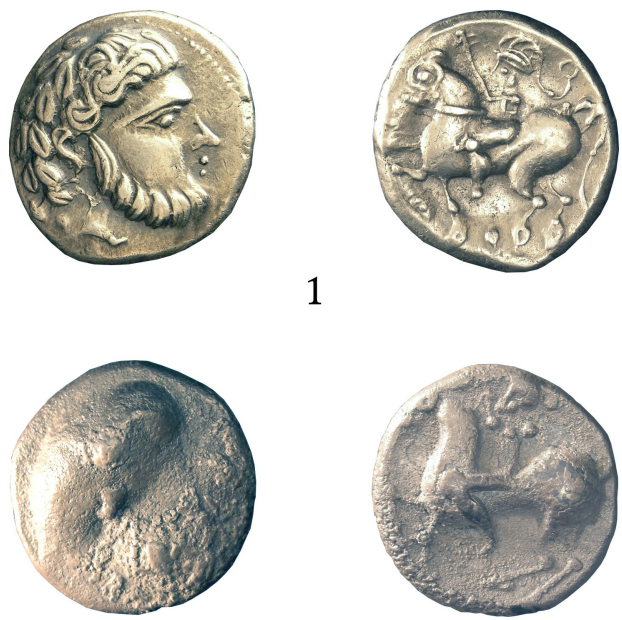

2
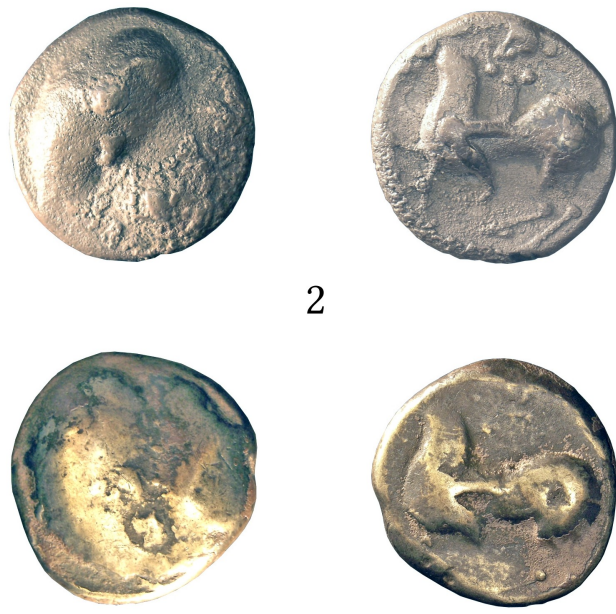

3

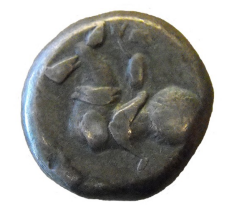

4

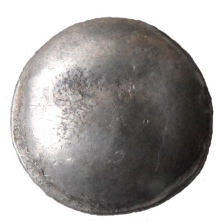

5

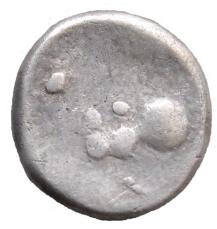

Fig. 2. 1. Baumreiter type (MNM 1.1954.3). 2. Early Lapujtő type with rider (MNM R.I. 6274). 3. Early Lapujtő type with traces of rider (MNM 49.1909.2). 4. Later Lapujtő type with horseman (MNM Dess. 802). 5. Later Lapujtő type (Cat. Nr. 3).
The Óhuta type (Pink 357-358), bearing a horse and five dots above is related to the Lapujtő type coins. This type was named after a hoard found in 1846, as these coins made up the largest part of it. The hoard was thoroughly dealt with by Péter Prohászka. ${ }^{25}$ The type can be derived from the early Lapujtő type. Óhuta type coins are known from Vác (Dess. 799), Diósgyőr (Dess. 1189), Gyertyánvölgy (HOM), ${ }^{26}$ and from the great rampart by Óhuta (HOM, MNM Ét). ${ }^{27}$ However the later variations of the Óhuta type can be found in Northern Slovakia, especially in the upper Vág/Váh and Hernád/Hornád districts, on the area of the Púchov culture. This group of coins were elaborately worked up by Eva Kolníkova, ${ }^{28}$ who dated the different variations of the group from the late 2nd - early 1st century $\mathrm{BC}$ to the early 1 st century $\mathrm{AD}$.

The Late Audoleon type / Audoleon derivation tetradrachm may give some help to date the Lapujto type coins. The Audoleon imitations are one of the earliest types of eastern Celtic coinage. In Hungary these can be the first Celtic coins both on typological, and both on metrological (they usually weigh more than 13 g) grounds. Their absolute chronological dating is based on the vessel of the Egyházasdengeleg (Nógrád megye), thus the coins were minted at the second third / third quarter of the 3rd century BC. ${ }^{29}$ The legend $\mathrm{AY} \triangle \Omega \Lambda \mathrm{EONTO} \Sigma$ is legible on some of the coins, while on the others only meaningless letter imitations are visible. These two types of Audoleon imitations (Pink 402 and Pink 415) can be found in several hoards in Nógrád, Heves and in the northeastern part of Pest megye (Mohora, Vác, Vámosgyörk)..$^{30}$ The later derivations of the type are known from scattered finds, ${ }^{31}$ one coin is known from the hoard of Ohuta ${ }^{32}$ found in 1846, and three exemplars are known from the Nagyhörcsökpuszta treasure..$^{33}$ The Óhuta treasure can be dated by its gold objects and a drachm with the head of Athena.

25 ProhászKa 2013.

26 HellebrandT 1992, nr. 6, 11.

27 Hellebrandt 1992, nr. 12, 14 and MNM Ét 30.1958.

28 Kolníkova 2004.

29 SzABÓ 1983.

30 TORBÁgyi 1997, 9.

31 Dunakeszi-Alagpuszta: MNM Ét L.2.2000. (11.91 g); Óhuta: NK 13 (1914) 18. (12.05 g); Miskolc: NK 7 (1908) 98 (12.00 g); Szirmabesenyő: Forrer 359 (11.78 g).

32 Prohászka 2013, 43 (11.52 g).

33 Gohl 1915, 123; FMRU 1, 270 ( $12.17 \mathrm{~g}$ and $12.70 \mathrm{~g}$ ). The second coin is omitted by FMRU, but it is in the MNM. The third coin is lost, its weight is unknown. 
Thus the Óhuta type coins and the Late Audoleon derivations can be dated to the late 2nd century BC (Fig. 3). ${ }^{34}$

Celtic tetradrachms of the Abasár hoard were made in the late 2nd century BC and the Lapujtő type drachm must be contemporaneous with them, as the different denominations were found together in Szontagh's treasure as well.

The fragment of Imitation of Philip II of Macedon - though the type cannot be specified according to its weight and depiction seems to be struck in an earlier phase of Celtic coinage; it was probably struck in the first half of the 2nd century $\mathrm{BC}$, or even earlier.
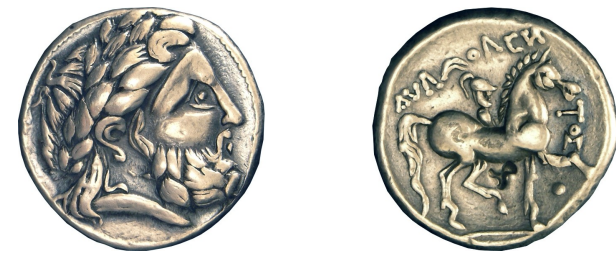

Fig. 3. Audoleon type (MNM N.I. 5356).

The first small size coin cannot be identified, as we were working with the photos only, and the photo of the reverse was lost. The second obol size coin is a previously unknown type. ${ }^{35}$ In the last decades more and more small silver fractions has turned up, due to the widely spread use of metal detectors (both legal and illegal), unfortunately mostly without finding place and archaeological context. From the archaeological excavations at Roseldorf in Lower Austria small silver coins are known from archaeological context. ${ }^{36}$ According to these the small denominations are typical not only at the end of the Celtic age, but they can be found in "urban" milieu, in commerce centres already in the 2 nd century BC. ${ }^{37}$

The Celtic coins of the Abasár hoard were obviously not made at the same place, though it is not possible to determine the location of minting or their manufacturers. Based on the finding places the Buckelavers Lapujtő types together with the smaller denominations were struck in the region of the Karancs Mountains. It is more difficult to determine the place of minting of the Audoleon derivation, as it was not consequentially minted where the earlier types were. In the western parts of the North Hungarian Mountains, in Heves, and in the north-eastern part of Pest megye Celtic population lived from the LTB2 period (Szob, Vác, Hatvan-Bódog, Hort, Petőfibánya). The increasing number of finds from the LTC period refers to larger population. ${ }^{38}$ Coinage also began at this time in the area.

The names of Celtic tribes are only known from the time of the Boian-Dacian conflict, but it is unknown how long the tribes had been living in the area. According to Tacitus (Germ. 43.) the Osi lived on the northern edge of the Great Plain, close to the Danube Bend; the Cotini, Anartii, and the Taurusci lived east of them. The inscription of Vinicius at Tusculanum ${ }^{39}$ also mentions people of the North Hungarian Mountains from Dacia to the Danube Bend. During his campaign that can be dated between $10 \mathrm{BC}$ and $1 \mathrm{AD}$ Vinicius subjugated the people of the northern part of the Great Plain; this is also mentioned by Augustus (Res Gestae 30). The Anartii (Upper-Tisza region) and the Cotini, whom are also known from inscriptions from Imperial times, as some groups settled in Pannonia, bore Dacian names at that time. It is possible that these people came from Dacia due to the strengthening of Dacian power

34 Kolníkova 2004, 35-38.

35 A similar coin was found in Fejér megye (the exact spot is not known) a few years ago.

36 DEMBSKi 2009.

37 ČIŽMAŘ ET AL. 2008; KolníKOVA 2012.

38 Hellebrandt 1991-1992, 101-102.

39 ILS 8965. 
probably in the second half of the 2nd century BC when Celtic presence markedly declined in Transylvania. ${ }^{40}$ Based on the relatedness of the Bartkranzavers (Crişeni) type and the Syrmian Krčedin type a southern - south-western migration of the Transylvanian Celts to Syrmia was supposed. ${ }^{41}$ A north-western migration from northern Transylvania is also plausible, which can be attested by the Buckelavers coins deriving from Baumreiter mit Bartkranzavers type. If different issuers are presumed to struck the two types of the Buckelavers coins, and these tribes lived here before the Dacian thrust, then the Osi may be manufacturers of the Lapujtő coins, while the Ó-huta type can be connected rather to the Cotini. However historical sources do not circumscribe exactly the habitation of the two tribes, nor can it be done based on the archaeological finds.

\section{Roman coins}

The Roman part of the hoard is also puzzling. It is not sure, whether the denarius of Trajan was also part of the hoard, or it is just a scattered coin found on the same spot. Based on the condition of the coins it belonged to the hoard, but the great interval between the coins of Tiberius and the last one would suggest the latter, though there are several hoards from the Barbarian confines of the Carpathian basin, which are similar in structure: ${ }^{42}$ Mákosfalva/Macovişte, ${ }^{43}$ Tibru, ${ }^{44}$ Gredistye/Grădiştea de Munte, ${ }^{45}$ Tövis/Teiuş (1 and 2) ${ }^{46}$ Boroskrakkó/Crică ${ }^{47}$ and Tisza/Tisa ${ }^{48}$ in Transylvania; Váchartyán, ${ }^{49}$ Békés-Gyula $2,{ }^{50}$ Nagyszalonta/Salonta, ${ }^{51}$ Szatmárnémeti/Satu Mare, ${ }^{52}$ and Békés-Gyula $3^{53}$ on the Great Plain; Arva ${ }^{54}$ and Barboşi ${ }^{55}$ from Moldavia. Based on the analogy of the above mentioned finds, the hoard was collected during a long period of time. ${ }^{56}$ The assembling was not continuous, but certain waves of accumulation can be detected.

The first part is made up of the Celtic coins. Although they are contemporaneous with some of the Roman coins, it is unlikely, that the latter get to the region at that time.

The second part is the Roman Republican denarii, and those of Augustus and Tiberius. Three similar hoards (Fig. 7) are known from the region: Sajóörös ${ }^{57}$ (Augustus), Rakamaz ${ }^{58}$ (Tiberius), and Jászdózsa ${ }^{59}$ (Nero). During the campaign of Vinicius ${ }^{60}$ Rome made contact

40 ZIRRA 1971; ZirRA 1975.

41 Popović 1987, 59.

42 VIDA 2012.

43 Krassó-Szörény vármegye, now judeţul Caraş-Severin, Romania; Ét. Archives 436/1892; VIDA 2008

44 judeţul Alba, Romania; GĂzDAC 2002, 469, with further references.

45 Hunyad vármegye, now judeţul Hunedoara, Romania; Ét. Archives 286/1879; WINKLER 1971.

46 Alsó-Fehér vármegye, now judeţul Alba, Romania; presumably two parts of a single hoard. Sucıu 2000, 57, with further references; TORBÁgyi 2006.

47 Alsó-Fehér vármegye, now judeţul Alba, Romania; Ét. Archives 229/1883; Ét. Archives 230/1883; unpublished.

48 Hunyad vármegye, now judeţul Hunedoara, Romania; Sucıu 2000, 58, with further references.

49 NK 1905, 98

50 now Gyula, Békés megye; RÉthy 1891; GoHL 1922-1923.

51 Ét. Archives 562/1898; SăşIANU 1980, 148-152; VIDA 2006.

52 WINKLER 1968.

53 RÉTHy 1891; GoHL 1922-1923.

54 MIHĂILESCU-BÎRLIBA 1980, 251-252, with further references.

55 MIHĂILESCU-BîRLIBA 1980, 291, with further references.

56 VIDA 2012, 190-191.

57 Simon - ToRbÁgyi 2013 (C. 4-5 coins were lost, Republic: 18, Octavian, 19-18 BC: 1).

58 Unpublished, some coins were lost, the others (Republic 194, Augustus 8, and Tiberius 1) are in Jósa András Múzeum, Nyíregyháza.

59 Unpublished, MNM Ét. 397/1905 (Republic: 103, Augustus: 4, Tiberius: 6, Nero, AD 64-65: 1).

60 KovÁcs 2005, 270. 
with the people of the area, the leaders might had been granted money or other benefits. Roman coins appear in significant quantity in the region. The Sajöörös hoard might be the evidence of this first Roman-Barbarian contact. The coin inflow did not continue, either because this kind of politics was not effective, or the appearance of the Sarmatians changed the power relations of the region. During the reign of Tiberius Rome was again concerned with the region, the new relations might be indicated by the hoards of Abasár, Rakamaz, and Jászdózsa. On the other hand it is also possible, that the coins got to Barbarian territory later, but the scarce coins of Caligula and Claudius I are just missing from the hoards incidentally.

The third part of the Abasár hoard is a single coin only, as it is not unusual amongst the hoards mentioned earlier. We cannot guess when this coin was exported.

The date of the burial cannot be determined, as the hoards of the Barbaricum indicate when the coins were acquired, ${ }^{61}$ and their burial might happened decades or centuries later.

\section{Abbreviations}

Ét: Éremtár (Coin Cabinet)

HOM: Herman Ottó Múzeum, Miskolc

MNM: Magyar Nemzeti Múzeum (Hungarian National Museum)

NK: Numizmatikai Közlöny

\section{References}

BMCC: Allen, D., Catalogue of the Celtic coins in the British Museum with supplementary material from other British Collections. Vol I. London 1987.

ČIžmař, M. - Kolníkova, E. - Noeske, H. 2008: Němčice -Viceměřice - ein neues Handels- und Industriezentrum der Latènezeit in Mähren. Germania 86, 655-699.

Dembski, G. 2009: Eigenprägungen und Fremdgeld - Die Fundmünzen aus Roseldorf. In: Holzer, V. (Hrsg.), Roseldorf - Interdisziplinäre Forschungen zur grössten keltischen Zentralsiedlung Österreichs. Wien, 87-101.

DEss: Gróf Dessewffy Miklós barbár pénzei. Budapest 1910.

DLT: De La Tour, H., Atlas de monnaies gauloises. Paris 1892.

EISNER, I. 1927: Mince T. Zv. barbarské na Slovensku a v podkarpatski rusi. Numismatický Časopis 3, $1-27$.

FMRU I: FITZ, J. (Hrsg.), Die Fundmünzen der römischen Zeit in Ungarn. Bonn - Budapest 1990.

ForRer: ForRer, R., Keltische Numismatik der Rhein- und Donaulande. Strassburg 1908

GĂZDAC, C. 2002: Monetary Circulation in Dacia and the Provinces from the Middle and Lower Danube from Traian to Constantine I (AD 106-337). Cluj-Napoca.

GoHL, Ö. 1901: Kelta és egyéb barbár érmeink technikai sajátosságai. Archaeologiai Értesítő 21, 303-421. 
GoHL, Ö. 1904: Újabb adatok a hazai kotinus és koisztobókus törzsek pénzeiről. Numizmatikai Közlöny 3, 4-8.

GoHL, Ö. 1911: Adalékok a hazai barbár pénzek corpusához. Numizmatikai Közlöny 10, 24-27.

GoHL, Ö. 1915: A nagyhörcsökpusztai barbár pénzlelet. Numizmatikai Közlöny 14, 123-127.

GoHL, Ö. 1922-1923: A görög pénzek forgalma Magyarországon. Numizmatikai Közlöny 21-22, 3-12.

GöBL, R. 1973: Ostkeltischer Typen-Atlas. Braunschweig.

Hellebrandt, B. M. 1991-1992: Heves megye kelta kori régészeti leletei. Agria 27-28, 85-134.

Hellebrandt, B. M. 1992: Miskolc kelta kora. in: RémiÁs, T. (ed.), Régészeti tanulmányok Miskolc korai történetéből. Miskolc, 33-74.

ILS: DessAu, H., Inscriptiones Latinae Selectae. Vol. III. 2. Berlin 1916.

KHM: Dembsкi, G., Münzen der Kelten. Sammlungskataloge des Kunsthistorischen Museums Bd. 1. Wien 1998.

Kolníkova, E. 1978: Keltské mince na Slovensku. Bratislava.

KolNíKOvA, E. 2004: Severoslovenské keltské mince hrbol'om na averze. Slovenská numizmatika 17, $11-52$.

Kolníkova, E. 2012: Nĕmčice - ein Macht-, Industrie- und Handelszentrum der Latènezeit in Mähren und Siedlungen am ihren Rande. Brno.

KovÁcs, P. 2004: Pannonia meghódítása és provinciává való szervezése. In: FeHÉr, B. - KovÁcs, B. (eds.), Korai földrajzi íók - a római hódítás kora. Fontes Pannoniae Antiquae 1. Budapest (2nd ed.), 264-277.

LANZ: Kostial, M., Kelten im Osten, Sammlung Lanz. München 1997.

Leszin, A. 1908: A borsodmegyei kelta pénzekről. Numizmatikai Közlöny 7, 97-101.

MinĂIlescu-BîrlibA, V. 1980: La monnaie Romaine chez les Daces orientaux. Bucureşti.

Mócsy, A. 1962: Pannonia. In: Pauly - Wissowa Realencyclopädie der classischen Altertumswissenschaft IX. Suppl. Stuttgart, 515-776.

MrÁv, Zs. - OtтomÁnYi, K. 2005: A pag(us) Herc(ulius) és vicusainak Terra Mater oltára Budaörsről. Specimina Nova 19, 71-118.

PINK, K. 1974: Die Münzprägung der Ostkelten und ihrer Nachbarn, 2. ergänzte und verbesserte Auflage. Braunschweig.

Popović, P. 1987: Le monnayage des Scordisques. Beograd - Novi Sad.

PredA, C. 1973: Monedele Geto-Dacilor. Bucureşti.

ProhÁszka, P. 2013: Az óhutai kelta kincslelet (1846). Numizmatikai Közlöny 110-111, 37-50.

RÉTHY, L. 1891: Békésgyulai éremleletek. Archaeologiai Értesitó 11, 189.

RIC: SutherLand, C. H. V., The Roman Imperial Coinage Vol. I Revised Edition. London 1984.

RRC: Crawford, M. H., Roman Republican Coinage. Cambridge 1974.

SĂşIANU, A. 1980: Moneda antică în vestul şi nord-vestul României. Oradea.

Simon, L. - ToRbÁgyi, M. 2013: Római köztársaságkori éremlelet Sajóörösről. Herman Ottó Múzeum Évkönyve. In press. 
Sucıu, V. 2000: Tezaure Monetare Din Dacia Romană şi Postromană. Cluj-Napoca.

Szabó, M. 1983: Audoleon und die Anfänge der ostkeltischen Münzprägung. Alba Regia 20, 43-56.

SzonTAgh, F. 1870: Archaeologiai levelek XXVI. Archaeologiai Értesító 2 (1870) 292-294.

ToRbÁGyi, M. 1997: Keltische Münzprägung im Gebiet Ungarns. Numismatische Zeitschrift 104-105, $7-17$.

ToRbÁgyi, M. 2000: Monete celtiche in Ungheria. Milano.

ToRBÁgyi, M. 2006: Roman coin hoards from Tövis (today Teiuş, county of Alba, Romania). In: GAIU, C. - GăzdAc, C. (eds.), Fontes Historiae. Studia in honorem Demetrii Protase. Bistriţa - ClujNapoca, 631-640.

VIDA, I. 2006: Two 2nd century coin hoards. In: GaIU, C. - GĂZdAC, C. (eds.), Fontes Historiae. Studia in honorem Demetrii Protase. Bistriţa - Cluj-Napoca, 657-666.

VIDA, I. 2008: The coin hoard of Mákosfalva / Macovişte. In: SPInEI, V. - MunTEAnu, L. (eds.), Miscellanea numismatica Antiquitatis. In honorem septagenarii Virgilii Mihăilescu-Bîrliba oblata. Iaşi, $229-238$.

VIDA, I. 2012: Kincsek és etnikum. 2-3. századi dák kincsek. In: Bíró, Sz. - VÁmos P. (eds.), Firkák II. Fiatal Római Koros Kutatók II. Konferenciakötete. Győr, 189-198.

VISY, Zs. 1993: Cotini in Pannonia. Specimina nova 9, 5-12.

WG: Fiala, E., Collection Ernst Prinz zu Windisch-Grätz. Prag 1900.

WinkleR, I. 1968: Tezaurul de denari romani de la Satu-Mare. In: BAder, T. (ed.), Tezaure monetare din județul Satu-Mare. Satu Mare, 19-34.

WinkleR, I. 1971: Tezaurul de denari romani descoperit la Grădiştea de Munte în anul 1879. Studii şi Cercetări de Numismatică 5, 283-302.

ZirRA, V. 1971: Beiträge zur Kenntnis des keltischen Latène in Rumänien. Dacia N.S. 15, 171-238.

ZIRrA, V. 1975: Influence des Geto-Daces et de leurs voisins sur l'habitat celtique de Transylvanie. In: Fitz, J. (ed.), The Celts in Central Europe: papers of the II. Pannonia Conference. Alba Regia 14, $47-64$. 


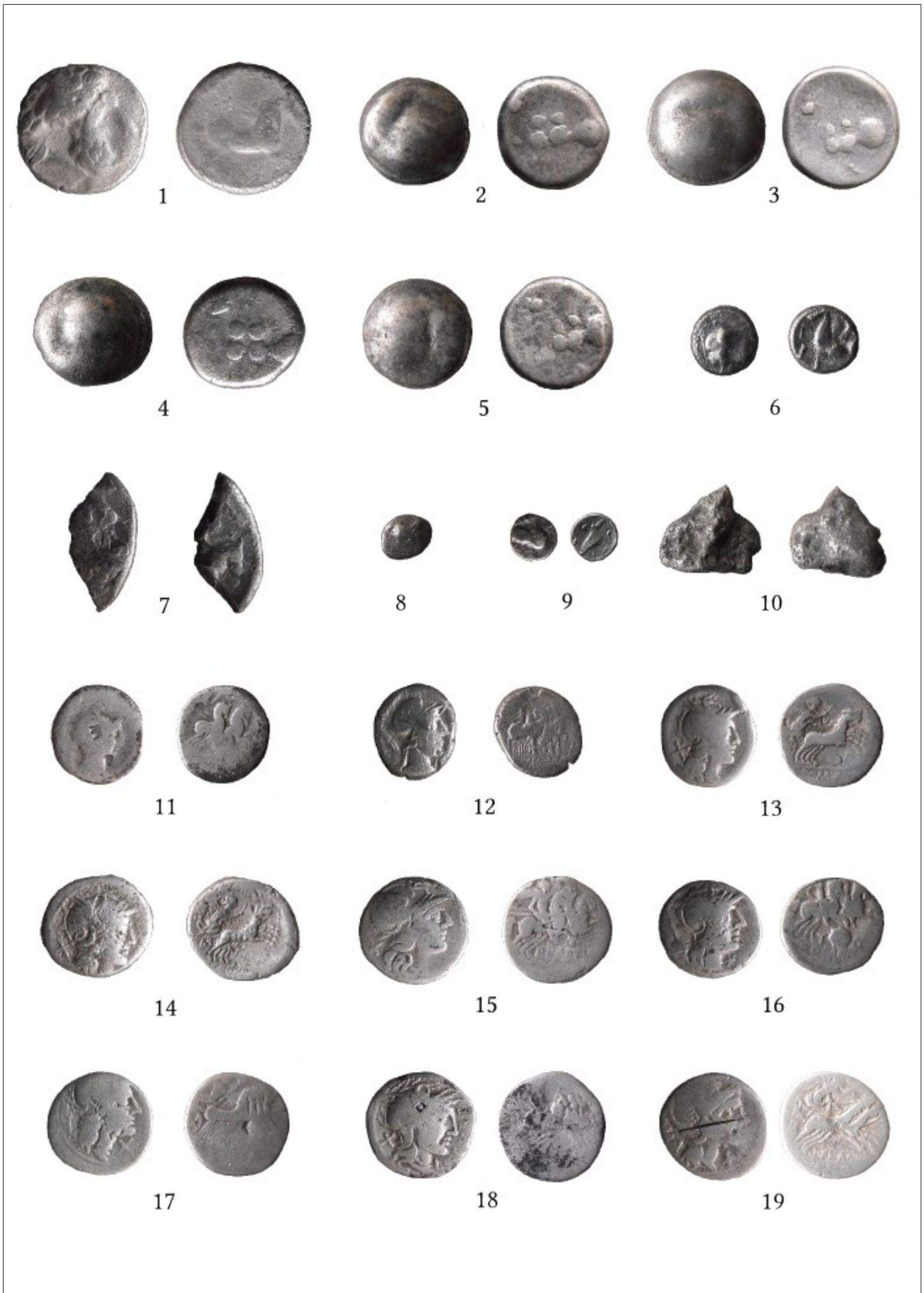

Fig. 4. The coin hoard of Abasár (Cat. Nr. 1-19). 


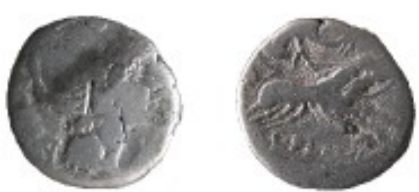

20

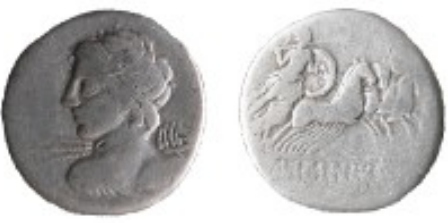

23

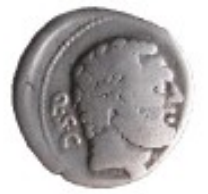

26

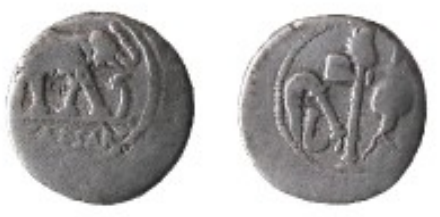

29
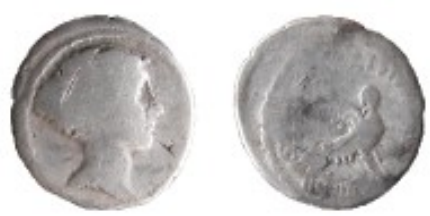

32

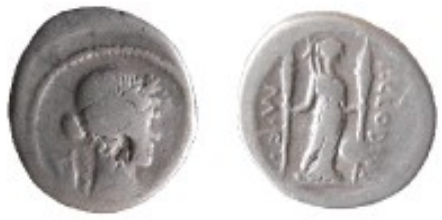

35
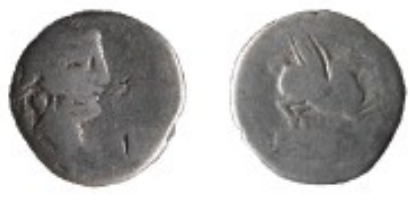

21

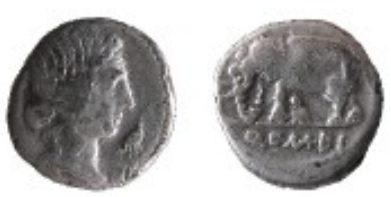

24

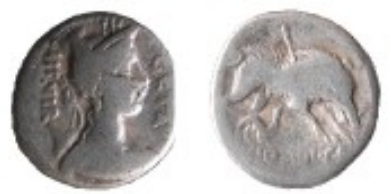

27
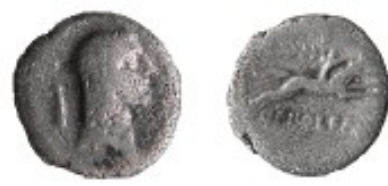

28

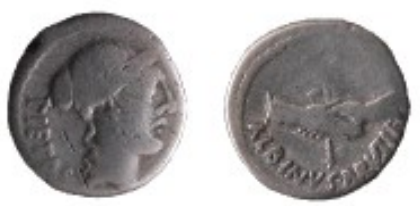

30

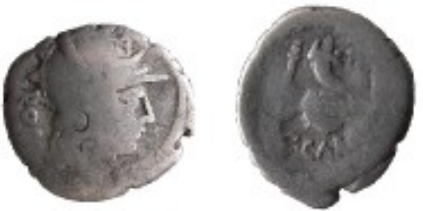

33
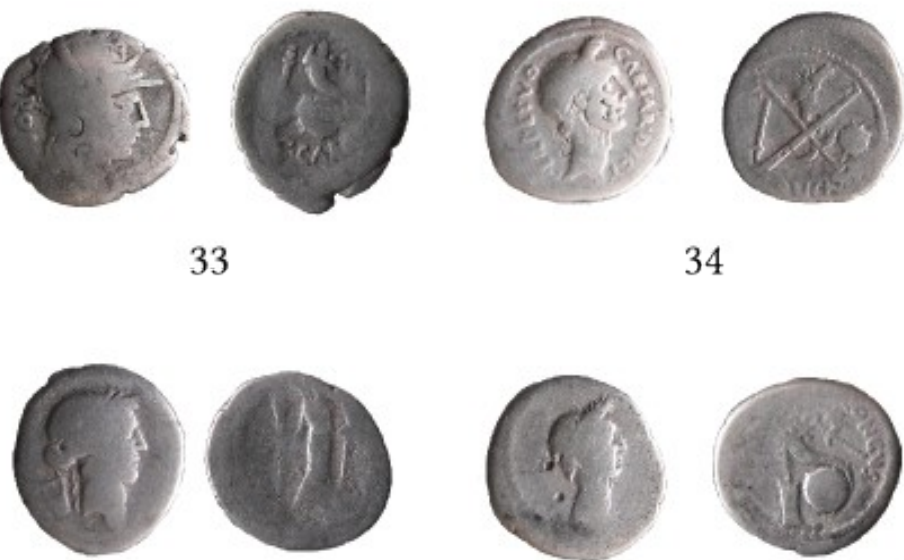

36

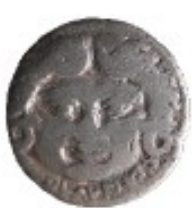

31

34
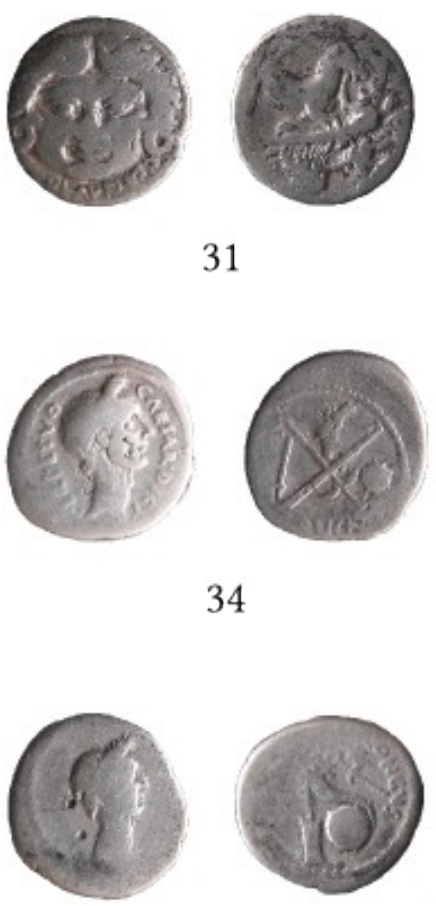

37

Fig. 5. The coin hoard of Abasár (Cat. Nr. 20-37). 


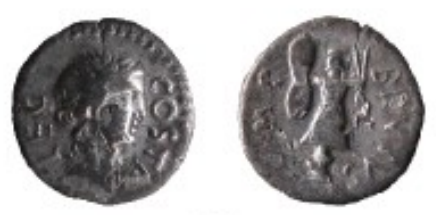

38

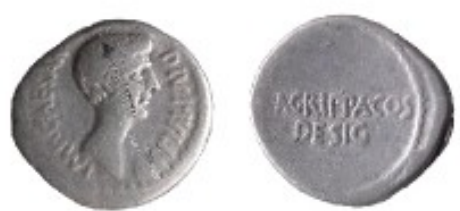

41

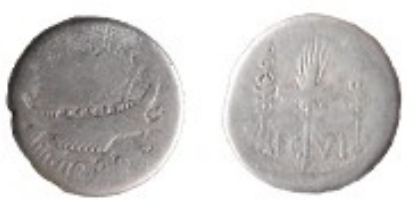

44

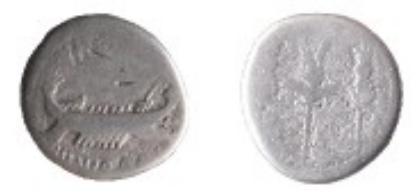

47

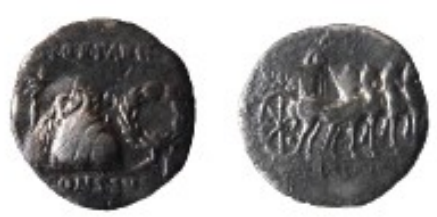

50
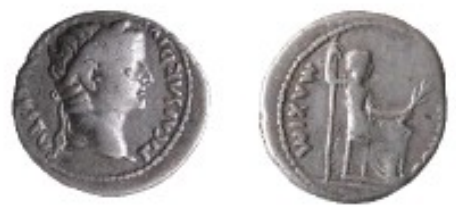

52

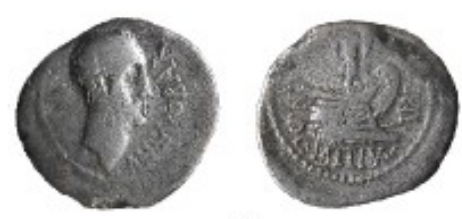

39

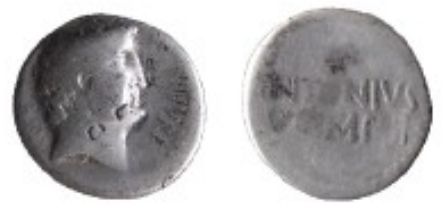

42

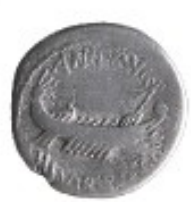

45
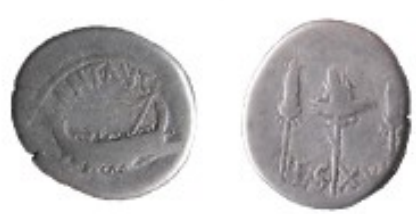

48
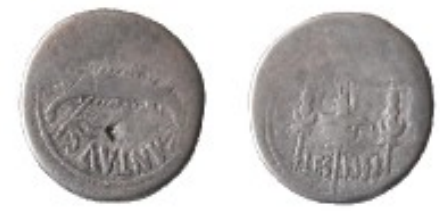

43

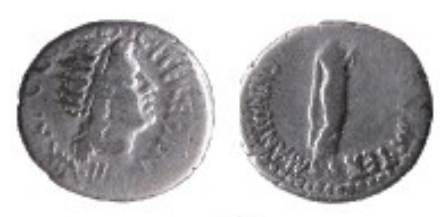

40

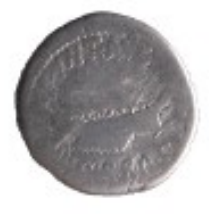

46
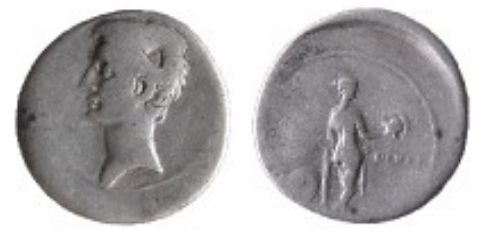

49

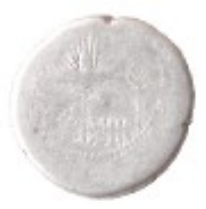

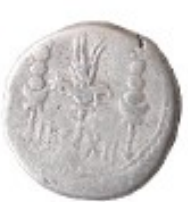

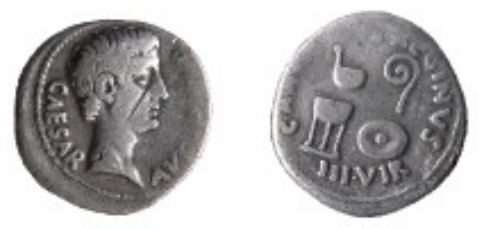

51

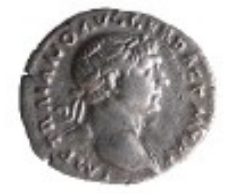

53

Fig. 6. The coin hoard of abasár (Cat. Nr. 38-53). 


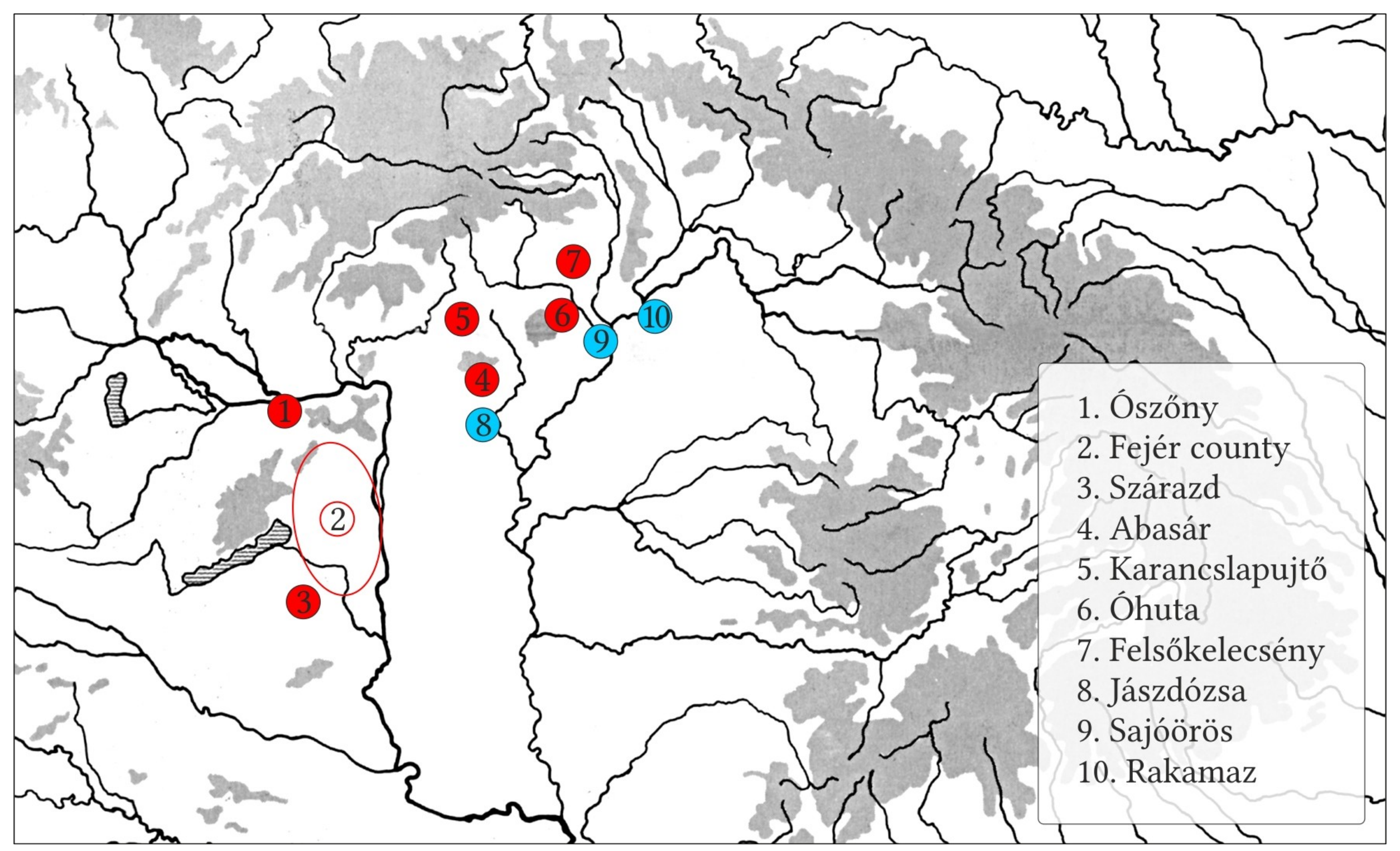

Fig. 7. Celtic (red) and Roman (blue) coin hoards mentioned in the article. 